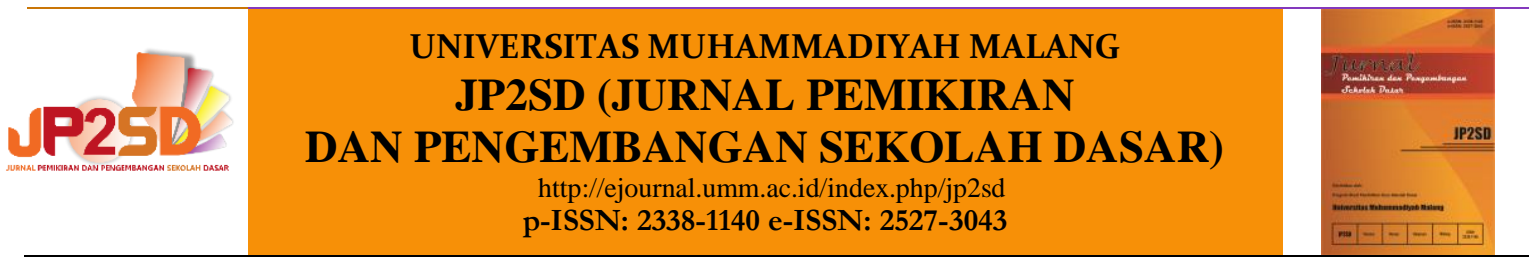

\title{
Instilling and Shaping Religious Character in Madrasah Ibtidaiyyah
}

\author{
Jamilah $^{\text {a1 }}$, Tri Sukitman ${ }^{\text {b2 }}$ \\ aDepartment of Primary Education, STKIP PGRI Sumenep, Indonesia \\ ${ }^{b}$ Department of Primary Education STKIP PGRI Sumenep, Indonesia \\ ${ }^{1}$ jamilah@ stkippgriumenep.ac.id, ${ }^{2}$ tri.sukitman@ stkippgriumenep.ac.id
}

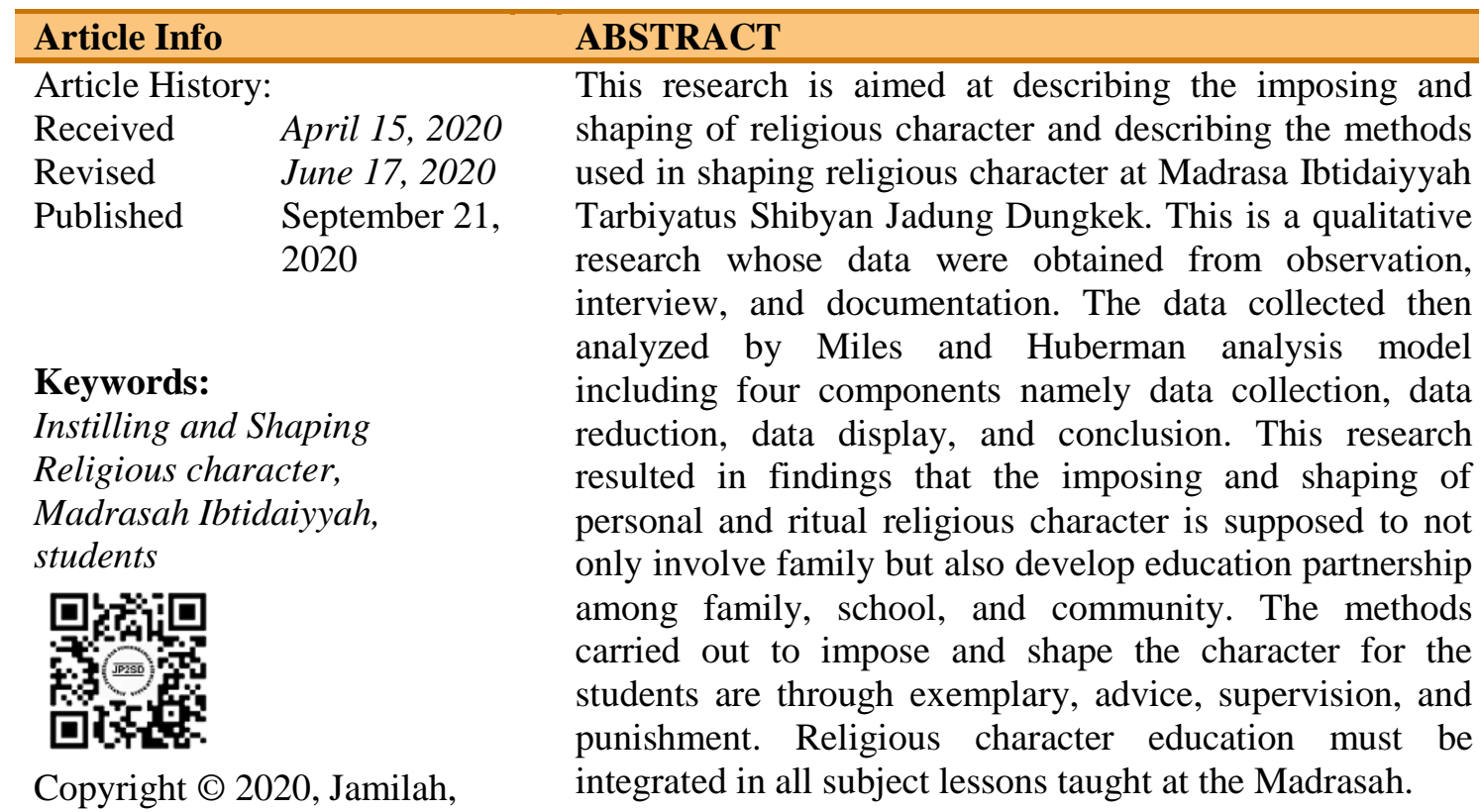

Tri Sukitman

This is an open access article under the CC-BY-SA license

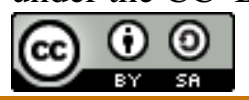

How to cite: Jamilah, Tri Sukitman. (2020). Instilling and Shaping Religious Character in Madrasah Ibtidaiyyah. Jurnal Pemikiran dan Pengembangan Sekolah Dasar, Vol 8 No 2, 118125. doi: https://doi.org/10.22219/jp2sd.v8i2.11884

\section{INTRODUCTION}

Education is needed by everyone in order to achieve good life. The focus of character shaping contains a set of references of character values and norms growing and become the references for the community. Character is specific and the foundation of every person. The understanding of character education at present time is expected to be able to develop children's talent and interest in accordance with the values of character education. 
The existence of various problems in various media shows that there is a crisis of national character education for examples fights among students, drugs abuse and crime, as well as lack of confidence in using domestic products. There is an indication of the decline in understanding and appreciation of the nation's noble values or inappropriate understanding about the values.

Such problems must be addressed through the character education process. Educating religious character is important because by religious character other characters can be improved (Marzuki \& Haq, 2018, p. 90).

Therefore character education needs to be instilled early starting from the family, school and community. Character building at school is a strategic place in the shaping of student's character other than family and community (Hamid, 2017, p. 3).

Nation character education can be seen from the philosophical, ideological, normative, historical and sociocultural dimensions (Pemerintah Republik Indonesia, 2010 , p. 1). In philosophical perspective, character education is the identity of the nation. In the aspect of ideology, character education is an implementation of Pancasila education. The normative side of character education as a tangible manifestation of the country's goal that is to protect the entire nation of Indonesia and the whole of the homeland of Indonesia in order to advance general prosperity, and to contribute to the implementation of a world order based on freedom, lasting peace, and social justice. Whereas, from a historical standpoint, the character education is a legacy from our ancestors and from a sociocultural perspective because this nation is a multicultural nation.

Implicitly, character education is stated in article 3 of the National Education System Law Number 20 of 2003 that: "National education serves to develop capabilities and shape the character and civilization of a dignified nation in order to educate the life of the nation. National education is aimed to develop the potentials in students to be more faithful and fear the only one God, having more excellent attitude, be healthy, knowledgeable, smart, creative, independent, and responsibly democratic citizen".

According to (Koesoema, 2010, p. 90-91), first, character is understood as a set of given conditions, exists and is forced to exist in us. Second, character that appears in humans is to control those conditions. The Nation's character problem is caused by various cases faced by the nation such as the fading implementation of the values of Pancasila, as well as moral and ethical shifts in society (Nasional, 2011, p. 5). Instruction is the process of transforming learning and teaching activities. Character development is comprehensively carried out in the learning process in all lesson subjects.

Mulyasa (2016, p. 4-7), states that the character is expected to be able to solve various existing problems, especially in the field of education and the process of preparing students starting from the planning, implementation, and evaluation of the education system. Teachers play an important role in shaping student's character and competency therefore, teachers must be creative and innovative in the learning process. By doing so, teachers can shape teir students' character according to their individual characters.

Character education is in the form of values education, character education, moral education, and character education which has objectives to provide role model, make good and right decisions, and provide exemplaries in daily life. Hence, in the long run, character education can produce graduates who contribute to build the nation without leaving noble characters. 
There are 18 values of character education, namely: (1) religious, (2) honest, (3) tolerance, (4) discipline, (5) hard working, (6) creative, (7) independent, (8) democratic , (9) eager to know, (10) nationalism, (11) homeland love, (12) respect for achievement, (13) friendly / communicative, (14) peace love, (15) fond of reading, (16) environment care, (17) social care, and (18) responsibility (Nasional, 2010). The spread of religion is one of the strategies to instil the values of student character by inculcating the values of character (Rokhmad, 2012, p. 80).

Asmani (2012), states that there are four kinds of character in educational process namely: (1) religious-based character education, (2) cultural value-based character education, (3) environment-based character education, and (4) self-potentialbased character education

Religious value is the main value in character education building because it is the original character of Indonesian people. The most important aspect and national education goal strategy is imposing the religious character education. Religious character is identical with religious behavior that contains positive values because religious character is very important starting point to shape the next character. Parents, teachers, and students are involved in the shaping of children's religious character. Imposing religious character is by developing character and behavior during children's growth. Instilling religious character values is intended to explore the potentials of spiritual, educating and training the spiritual potentials in human self. Thus, religious human is characterized human. The ways that can be carried out to strengthen character education are headmaster's regulation, the implementation of teaching and learning process, extracurricular activity, and culture as well as behavior conducted continuously by the school's community(Sahlan, 2010, p. 77).

Krauss (2005), in his instrument "The muslim religiosity-personality inventory says that the main foundation in building religious character is Islamic attitude and behavior reflected in daily life. The dimensions as the references of the religious character building are (1) dimension of self-relationship, (2) dimension of human relationship with other creatures, (3) dimension of human relationship with Allah. The instilling and shaping religious character programs at school must be continuously and sustainably carried out. It is indeed, everything conducted every day will be wellinstalled in student's self. It is in the line with (Wibowo, 2013, p. 21-22), who says that habituating at school can develop character education values. Thus, school culture is the key of success in building religious character at school.

The urgency of imposing religious character has become the research object of various researches on character education. This research will pay attention to the ways how the instilment and development of religious character at Madrasa Ibtidaiyah Tarbiyatus Shibyan are. In addition, this research will also discuss about the methods implemented to religious character building at Madrasa Ibtidaiyah Tarbiyatus Shibyan.

\section{METHOD}

This is a qualitative research (Sugiyono, 2014, p. 31) which has intention to know the instilment and method in religious character building at Madrasa Ibtidaiyah Tarbiyatus Shibyan. This research was conducted in August 2019 until December 2019 at MI Tarbuyatus Shibyan Jadung, Subdistrict Dungkek, Sumenep Regency.

Madrasah Ibtidaiyah Tarbiyatus Shibyan Jadung Dungkek is one of the elementary educations which specifically plans and implements religious character. This can be seen from the objectives stated (the visions and missions of Madrasa) and other 
supporting activities such as the habituating as well as extracurricular activities. Among the habitual activities routinely done are reciting Surah Yasin, Al Qur'an, Morning ceremony, and so on. Meanwhile, the extracurricular activities are scouting, drum band, qiro'ah and qasidah.

Sugiyono states that a population is an area with its specific object and characteristics (Sugiyono, 2014, p. 117). The students of MI Tarbiyatus Shibyan are the population of this research. The reason in deciding the population in this research is by using the sample of the students whose characters can still be habituated every day.

The sample of this research resulted in the information of data drawn and then developed through purposive sampling namely technique of sample decision by certain considerations (Sugiyono, 2014, p. 117). The decision in using Madrasa Ibtidaiyah as the research target is that $\mathrm{MI}$ is a formal elementary education institution level where its students are still in the golden age in which they can be directed more easily towards better character building

The techniques of data collection used are observation, interview, and documentation. The observation of this research was used to measure the implementation of character education model at MI Tarbiyatus Shibyan. In the observation process, the researcher observed and gave evaluation to the instructional model done by the teacher. Meanwhile, the interview was used to strengthen the observation. The documentation in this research was to give overview of the portraits of the research activities. The interview was also used to find out the model of an effective character education for the students. The various data collected then analyzed by using qualitative developed by Miles and Huberman. According to(Miles, Matthew B and Huberman, 1992, p. 145) the phases of qualitative data analysis are data collection, data reduction, data display, and conclusion.

\section{RESULTS AND DISCUSSION}

\section{The Research Subject's Characteristics}

The characteristics of the research subject of religious character education are as follow:

Table 1. Research Subject

\begin{tabular}{lll}
\hline & Frequency & Percent $(\%)$ \\
\hline Male & 60 & 50 \\
Female & 60 & 50 \\
Total & 120 & 100 \\
\hline
\end{tabular}

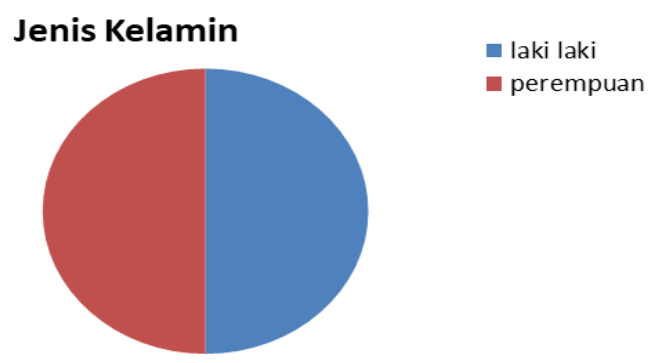

Figure 1 Respondent based on gender 
Based on table 1 and figure 1 above, it can be seen that the research population are 120 students. $60 \%$ or $50 \%$ students are male and 60 or 50 students are female.

\section{The Result of Religious Character Scores}

To know the score of religious character, in this case by using high, moderate, and low categor

Table 2. Religious character score

\begin{tabular}{|c|c|c|c|c|}
\hline \multirow{2}{*}{\multicolumn{2}{|c|}{ Student }} & \multicolumn{3}{|c|}{ Religious Character } \\
\hline & & High & Moderate & Low \\
\hline \multirow{4}{*}{ Gender } & Male & 40 & 20 & \\
\hline & & 0,66 & 0,34 & \\
\hline & Female & 43 & 17 & \\
\hline & & 0,72 & 0,28 & \\
\hline
\end{tabular}

The comparison of religious character scores are equals. Specifically, the average score can be seen in table 3 .

Table 3. The Average score of religious character indicators

\begin{tabular}{llll}
\hline Dimension & Indicator & Male & Female \\
\hline Character & Personal & 4,16 & 4,19 \\
Religius & Social & 4,12 & 4,10 \\
& Ritual & 3,98 & 3,89 \\
\hline
\end{tabular}

\section{Discussion}

Character education in Indonesia has been implemented since several years ago. The character education implemented at home for children who come from middle to lower economy level faces some difficulties since the majority of the students only get character education at school therefore, the result is not like what has been expected. Besides the economy factor, from the perspective of the bad environment where the students live may affect the character education for the children.

As what has been shown in table 2, the students of MI Tarbiyatus Shibiyan have high religious character score. This religious character dimension score shows that this research does not get along with the researches which claim that female students are more religious compared to male students. The school including the teachers' role in realizing the instilment of character is very important.

Teachers are supposed to make plan of the character values integrated in the instruction. It is important to remember that religious character values integrated in the lesson subjects by the teachers must be adjusted to the learning materials based on the standard of competency and basic competency. In simple terms, the basic character values developed through the instruction is a religious dimension which is the attitude and behavior of obedience in carrying out the religious teachings they believe in, tolerance of the worship of other religions and living in harmony and peace with followers of other religions.

According to the result of the research conducted by Warsiyah (Warsiyah, 2018) religious character in Indonesia is mainly affected by environmental factors namely 
family, school, and community. Personal character is higher compared to the other character dimensions. Religious values include the value of worship, the value of jihad, the value of trust and sincerity, as well as moral values and discipline. The religious character building in Madrasa is a strategic means because throughdiscipline religious teachings can shape a good and polite personality.

Based on the findings of the interview it can be described that the religious character building is the madrasa's program that needs to be accustomed to in educational programs. These programs must be carried out continuously and sustainably. The program can be implemented in routine and spontaneous activities. Another goal of holding habituation is to reduce the moral decadenceall this time.

The results of the observation show that in the begining of the lesson activities the teacher made a habit by carrying out a prayer and reciting short surah to instill religious attitudes. The religious character values reflect the value of faith in God Almighty which is manifested in the behavior of carrying out religious teachings that are adhered to anti harassment, not force the will, love the environment and protect the weaks.

The character in Madrasah Ibtidaiyah is built through a relatively long time. So that religious character development is also habituated. The values such as discipline, honesty, responsibility, tolerance, empathy, patience and other cultural values are religious characters that the students have.

The process of imposing the religious character values in learning activities is a series of activities to establish communication so that there is a good relationship between the teachers and the students. There are several obstacles in the imposing and shapingthe religious character, namely the lack of parental support and the negative impact of some printed and electronic media as well as the lack of student discipline in the activities habituation at school.

Personal indicators in character building are creating religious culture through worship activities or enhancing relations with God both in quality and quantity. For example praying in congregation, reciting the Qur'an, and praying together.

Social indicators in religious character building are maintaining good relations amongthe teachers, students, parents and the community. In developing this religious character, it is carried out routinely so that it runs optimally.

The religious tolerance is shown by the attitude of giving opportunities to conduct worship activities and to mutually give respect one another with those who are carrying out worship. Strengthening religious character refers to the introduction, deepening and implementation of religion carried out by the students.

The efforts to shape and foster personal, social, and ritual religious characters must involve the families as well as develop educational partnerships namely family, school and community since without the support of those three elements, it is difficult to make progress. Thus, to shape religious character, the education must be carried out at home, school, and community.

The religious character building needs the assistance of habituation in the teaching and learning process. This assistance can be done directly such as praying and reciting the Qur'an.

The guidance done by family can be in the forms of daily behaviors at home such as giving examplaries to children in accordance with the character to be shaped, solving problems with children although they are frequentlyannoying.Such a guidance 
is what has been expected by a teacher in shaping the children's character and however, the succes of religious character building certainly depends on the children themselves.

The religious values dimension above have become the references of character education plan. Those religious dimension indicator makes it easy for the teachers to implement the religious values at school. Universal religious values that can be shaped in the form of characters are very important since the students' belief about the value of religious characters require constructive motivation in character education.

Madrasah Ibtidaiyah Tarbiyatus Shibyan in addition to forming religious character also uses various forms of religious character education including the methods of exemplary, counseling, supervision, and punishment. In addition to these methods, in MI Tarbiyatus Shibyan habituation and religious character building carried out by enhancing practices and examples. By doing so,the students become more active in the learning process however, the enhancements must be in accordance with the conditions of the character of each student.

Fostering religious character for students is carried out in the form religious activities at schools so that students will eventually become religious people.Exemplary method, for example, by the way the teacher exemplifies students in performing prayers, fasting, alms, saying salam when meeting other students, living in harmony, and so forth.

The learning process performed by the teacher in the religious character building is that the subject must be in accordance with the surrounding life, learning starts from exemplary, telling the stories of inspirational figures. The process of integration in subjects is carried out starting from the beginning of the lesson until the lesson is finished. Thus, character education must be integrated in religious education.

\section{CONCLUSION}

The result of this research shows that religious character at the level of madrasa ibtidaiyyah is at utmost importance to assure the achievement of the national educational objectives thoroughly. The learning process is considered to be successful provided that the students have understood their environment as well as their own selves. The imposing and shaping of religious character are through personal, social, and ritual indicators. The method of imposing and shaping religious character for the students are through exemplary, advice, supervision, and punishment methods.

\section{REFERENCES}

Asmani, J. M. (2012). Panduan Internalisasi Pendidikan Karakter Di Sekolah (3rd ed.). Diva Press.

Hamid, A. (2017). Pendidikan Karakter Berbasis Pesantren (Pelajar dan Santri dalam Era IT \& Cyber Culture) (1st ed.). Imtiyaz.

Koesoema, D. (2010). Pendidikan Karakter Strategi Mendidik Anak Di Zaman Global (2nd ed.).

Krauss, S. (2005). Development of The Muslim Religiousity-Personality Inventory for Measuring The Religiousity of Malaysian Muslim Youth. Universiti Putra Malaysia Kuala Lumpur.

Marzuki, M., \& Haq, P. I. (2018). Penanaman Nilai-Nilai Karakter Religius Dan Karakter Kebangsaan di Madrasah Tsanawiyah Al Falah Jatinangor Sumedang. Jurnal Pendidikan $\quad$ Karakter, $\quad 8(1), \quad 84-94$. https://doi.org/10.21831/JPK.V8I1.21677 
Miles, Matthew B and Huberman, A. M. (1992). Analisis Data Kualitatif. UI Press.

Mulyasa, E. (2016). Guru dalam Implementasi Kurikulum. Remaja Rosda Karya.

Nasional, K. P. (2010). Bahan Pelatihan Penguatan Metodologi Pembelajaran Berdasarkan Nilai-Nilai Budaya untuk Membentuk Daya Saing dan Karakter Bangsa: Pengembangan Pendidikan Budaya dan Karakter Bangsa. Kementerian Pendidikan Nasional, Badan Penelitian dan Pengembangan, Pusat Kurikulum.

Nasional, K. P. (2011). Panduan Pelaksanaan Pendidikan Karakter. Badan Penelitian Dan Pengembangan Pusat Kurikulum Dan Perbukuan.

Pemerintah Republik Indonesia. (2010). Kebijakan Nasional Pembangunan Karakter Bangsa Tahun 2010-2025.

Rokhmad, A. (2012). Radikalisme Islam Dan Upaya Deradikalisasi Paham Radikal. Walisongo: Jurnal Penelitian Sosial Keagamaan, 20(1), 79. https://doi.org/10.21580/ws.20.1.185

Sahlan, A. (2010). Mewujudkan Budaya Religius Di Sekolah: Upaya Mengembangkan PAI dari Teori ke Aksi. UIN-Maliki Press.

Sugiyono. (2014). Metode Penelitian Pendidikan (Pendekatan Kualitatif, Kualitatif dan $R \& D)$. Penerbit Alfabeta.

warsiyah. (2018). Muslim Youth Religiosity: With The References Of Gender Differences And Educational Environment. TARBIYA: Journal of Education in $\begin{array}{llr}\text { Muslim } & \text { Society, } & \text { 5(1), } \\ \text { https://doi.org/https://doi.org/10.15408/tjems.v5i1.7842 }\end{array}$

Wibowo, A. (2013). Manajemen Pendidikan Karakter Di Sekolah. Pustaka Pelajar. 